Journal An-Nafs: Kajian Penelitian Psikologi

http://ejournal.iai-tribakti.ac.id/index.php/psikologi e-ISSN: 2549-6166

p-ISSN: 2528-0600

\title{
HUBUNGAN HARDINESS DENGAN EMOTION FOCUSED COPING PADA ANAK DAN REMAJA YANG SEDANG BERHADAPAN DENGAN HUKUM (ABH)
}

\author{
Uswatun Hasanah \\ patner.psikologi@gmail.com \\ Institut Agama Islam Tribakti Kediri \\ https://doi.org/10.33367/psi.v4i1.676
}

\begin{abstract}
Abstraksi
Penelitian ini bertujuan untuk mencari hubungan Hardiness dengan Emotion Fokused Coping pada anak remaja yang sedang berkonfik dengan hukum. Hipotesis penelitian ini adalah "Ada hubungan Hardiness dengan Emotion-focused Coping pada anak yang berhadapan dengan Hukum $(A B H)$. Sebagai variable bebasnya adalah Hardiness (X) dan varibel tergantungnya adalah Emotion-focused Coping (Y). Subyek penelitian ini adalah 60 orang anak remaja yang sedang berhadapan dengan hukum di Kab. Jombang. Metode pengumpulan data menggunakan wawancara, dokumentasi dan skala pengukuran berupa angket Hardiness dan Emotion-focused Coping, Observasi sebagai pelengkap data. Teknik quota sampling, Analisis data menggunakan Analisis Produc Moment Hasil penelitian menunjukan bahwa hasil korelasi antara variable hardiness dengan Emotion-fokused coping (EFC), yang dilakukan denga analisis korelasi product moment dari Karl Pearson dengan jumlah subyek $\mathrm{N}=60$ diperoleh koefesien $\mathrm{rxy}=$ 0,$437 ; p=0,038(p<0,001)$, hasil analisis tersebut menunjukan ada hubungan yang sangat signifikan antara hardiness dengan Emotion-fokused coping. Artinya semakin tinggi Hardiness maka semakin tinggi Emotion-focused Coping pada individu, sebaliknya semakin rendah Hardiness maka semakin rendah pula emotionfocused coping anak berhadapan dengan hukum $(\mathrm{ABH})$
\end{abstract}

Kata Kunci : Hardiness, Emotion Focused Coping, Anak dan Remaja 


\begin{abstract}
This study aims to find out the correlation between Hardiness and Emotion-Focused Coping in teenagers who are in conflict with the law. The research hypothesis is "There is a correlation between Hardiness and Emotion-focused Coping in teenagers with law problem $(A B H)$. The independent variable is Hardiness $(X)$ and the dependent variable is Emotion-focused Coping $(Y)$. The subjects of this study were 60 teenagers with the law problem in Kab. Jombang. The method of data collection used were interviews, documentation and measurement scales in the form of Hardiness and Emotionfocused Coping questionnaires, observations as complementary data, Quota Sampling Technique. Analysis of data used was Product Moment Analysis. The results showed that the tight correlation between hardiness and Emotion-focused coping (EFC) which was carried out with product moment correlation analysis from Karl Pearson with the number of subjects $N=60$ obtained rxy coefficient $=0.437 ; p=0.038$ ( $p$ <0.001). The results illustrated a very significant significant between hardiness and Emotion-focused coping. That is, the higher Hardiness, the higher Emotion-focused Coping on individuals. the lower the Hardiness, the lower emotionfocused coping the in children with law problem $(A B H)$.
\end{abstract}

Keyword: Hardiness, Emotion Focused Coping, Children and Teenages

\title{
Pendahuluan
}

Anak remaja masa kini banyak menghadapi permasalahan yang kompleks dan telah banyak diberitakan di media masa. Permasalahan yang dihadapi oleh remaja, tidak hanya merugikan diri sendiri, namun dampaknya juga kut dirasakan oleh masyarakat, hal ini dikhawatirkan dapat terjadi pada anak- anak yang menginjak masa remaja seperti keterlibatan remaja dalam kasus pelanggaran hukum misalkan psikotropika, perkelahian, tawuran, pemerkosaan, perusakan fasilitas umum, bolos sekolah, dan bunuh diri.

Masa remaja awal merupakan suatu masa fluktuasi emosi naik turun suama hati berubah-ubah berlangsung lebih sering (Rosenblum \& Lewis 2003). Terjadinya perubahan hormon dan fisik sering menimbulkan persoalan tersendiri bagi remaja muda

54 | Journal An-nafs: Vol. 4 No. 1 Juni 2019 
dapat merasa sebagai orang yang paling bahagia dan kemudian merasa sebagai orang yang malang di saat lain. Dalam banyak kasus intensitas dari emosi remaja berada di luar proporsi dari peristiwa yang membangkitkanya. (Steinberg \& Levine, 1997) . Remaja muda dapat merajuk ,tidak mengetahui bagaimana caranya mengekspresikan perasaan mereka cukup, dengan sedikit atau tanpa provokasi sama sekali mereka dapat menjadi sangat marah hal ini mengingat bahwa usia praremaja sangat rentan terhadap pengaruh internal dan eksternal.

Di Indonesia pelanggaran terhadap hak anak dan anak berhadapan dengan hukum (ABH) sepanjang tahun 2018 KPAI mencatat terdapat 4.885 kasus anak yang berhadapan dengan hukum. Khususnya di wilayah Jombang mencapai 68 kasus sepanjang tahun 2017-2018.Kasus anak berhadapan dengan hukum merupakan masalah krusial yang harus segera ditangani. Konsekuaensi yang harus dihadapi anak berhadapan dengan hukum (ABH) cukup banyak mereka harus menjalani proses hukum yang memakan waktu cukup lama,misalnya proses penyidikan, persidangan hingga putusan memakan waktu berbulan-bulan belum lagi tekanan psikologis dan stigma bermasalah dan pembawa masalah di dalam lingkunganya , untuk menghadapi kondisi yang cukup berat ini kemungkinan akan terjadi banyak beban psikologis tentunya, dimungkinkan dapat terjadi krisis indentitas akibat tekanan yang berat sehingga menimbulkan pemicu stress pada saat anak berhadapan dengan hukum, sehingga terjadi Krisis identitas timbul akibat dari konflik internal berawal dari masa transisi yang di alami oleh remaja (Atkinson \& Hilgard, 1999).

Akibat adanya krisis identitas seseorang remaja akan mengalami kecemasan yang tinggi, hal tersebut didukung oleh Fuhrman (1990) yang menyatakan remaja akan mengalami peningkatan frekuensi cemas karena banyaknya masalah akibat adanya perubahan fisik, psikologis dan sosial. Goleman (1995) menyebutkan banyak remaja mengalami masalah emosional yang cukup berat seperti mudah marah, mudah terpengaruh, putusasa, 
sulit mengendalikan dorongan hati, sulit mengambil keputusan dan memotivasi diri sendiri. Berbagai peristiwa atau kejadian yang di alami remaja akan berpengaruh dalam proses perkembangannya. Sehingga dalam mengatasinya cenderung mengarah pada pengaturan respon emosinya dengan beberapa cara, antara lain yang biasa digunakan individu dalam pengaturan emosinya adalah dengan berfikir dan memberikan penilaian mengenai situasi yang penuh tekanan tersebut anak remaja yang sedang berhadapan dengan hukum dalam proses untuk tumbuh dan berkembang harus mengembang potensinya dan harus memiliki tingkat ketahanan (Hardines) yang kuat dalam mengahadapi masalah yang sedang dihadapinya diharapkan memiliki coping yang positif dan lebih kontruktif dalam menghadapi stressor dan tekanan yang ada, yaitu melalui penyelesaian masalah yang berfokus pada pokok permasalahan (problem focused coping) (Sarafino, 1998).

Kemampuan menghadapi masalah sangat dipengaruhi oleh ketahanan individu memberikan perlawanan dalam menghadapi suatu persoalan. Kobasa (1970) mendefinisikan hardiness sebagai sebuah pendekatan proses kognitif yang memiliki ketahanan melawan situasi yang penuh tekan/ stress dengan adanya kemampuan respon afektif, kognitif dan psikomotorik yang melekat. Apabila individu mempunyai kepribadian yang memiliki daya tahan terhadap masalah yang dihadapinya, tidak mudah frustasi, tertekan, takut kekhawatiran yang berlebihan dalam situasi yang menekan tentunya akan memberikan pengaruh terhadap meminimalisir perilaku menyimpangatau abnormal.

Berdasarkan fenomena serta uraian yang telah dikemukakan dan dipaparkan di atas, penulis merasa menjadi tertarik dan terdorong untuk melakukan penelitian mengenai "Hubungan Hardiness dengan Emotion Focused Coping pada padaremaja yang sedang berhadapan dengan hukum. 


\section{Pengertian Hardiness}

Tipe kepribadian yang mempunyai kemampuan dan daya tahan terhadap tekanan/ stress yang sering dibicarakan akhir akhir ini adalah "ketabahan" (hardiness atau hardy personality) yang merupakan gagasan konsep dari Kobasa. Kobasa (1979) mendefiniskan hardiness sebagai sebuah pendekatan proses kognitif yang memiliki ketahanan melawan situasi yang penuh stress dengan adanya kemampuan respon afektif, kognitif, dan psikomotorik yang melekat.

Maddi (1982) menjelaskan hardiness adalah karakteristik kepribadian yang mempunyai fungsi sebagai sumber perlawanan pada saat individu menghadapi peristiwa - peristiwa yang menimbulkan stress. Hardiness adalah salah satu bentuk kepribadian yang menunjukkan ketangguhan melawan peristiwa - peristiwa traumatik yang dapat menimbulakn stress ( King et al, 1998, Bartone, 2000)

Individu yang hardiness akan tetap lebih sehat ketika berada di bawah tekanan daripada individu yang kepribadiannya kurang tahan terhadap tekanan. Hal ini karena mereka memiliki kemampuan yang lebih baik dalam mengahadapi stressor dan tidak mudah merasa cemas dan tegang dengan kejadian kejadian yanga ada (Kobasa, 1978, dalam Sarafino, 1998)

Orang yang tinggi hardinessanya akan lebih efektif dalam menghadapi situasi yang penuh tekanan / stress daripada orang orang yang kurang hardinessnya, sebagai contoh yaitu dengan berusaha menghadapi masalah atau mengubah situasi negatif menjadi situasi positif (Halohan dan Moos, 1985:Williams, dkk, 1992 dalam Sarafino, 1998). Ditambahkan juga bahwa individu yang hardiness, kurang menunjukkan ketegangan psikologis ketika berada di dalam stress daripada individu yang kuranghardiness(Contrada, 1989 dalam Sarafino, 1998). Individu yang hardiness dapat mengambil tindakan langsung pada masalah, menyatukan dalam kehidupannya, dan belajar dalam mengambil nilai yang bermanfaat untuk masa depan. Dengan demikian, individu dengan kecenderungan hardiness adalah 
Uswatun Hasanah | Hubungan Hardiness dengan Emotion

individu yang mampu bertahan untuk lebih baik ketika berhadapan denganstressor daripada individu yang kurang hardiness (Williams, dkk, 1992 dalam Taylor, 1995)

\section{Aspek -aspekHardiness}

Kobasa (1979) menyatakan bahwa hardiness menunjukkan adanya commitment, control, dan challenge. Individu yang berkepribadian hardiness memiliki kesungguhan dalam tujuan yang berarti (commitment), melihat perubahan bukan sebagai beban tetapi sebagai sebuah hal yang normal dalam hidup (challenge), dan dapat menguasai setiap kejadian dalam hidup (control).

Taylor (1995) juga menyebutkan bahwa hardiness terdiri dari perasaan akan commitment, yaitu kecenderungan untuk melibatkan diri dalam apapun yang dihadapi oleh seseorang. Keduanya, kenyakinan akan control, yaitu perasaaan bahwa seseorang dapat menyebabkan timbulnya suatu kejadian dalam kehidupan dan orang tersebut dapat mempengaruhi lingkungannya, dan challenge, yaitu kemauan untuk melakukan perubahan dan berhadapan dengan aktivitas - aktivitasnya baru yang dapat memberikan kesempatan untuk tumbuh.

Secara teoritis, gabungan dari ketiga aspek tersebut di atas merupakan unidimensional, bukan multidimensional, dan merupakan satu faktor (Funk dan Houston, 1987). Commitment, control, dan challenge menjadi satu kesatuan dan bukan merupakan bagian yang terpisah-pisah dalam diri seseorang yang berkepribadian hardiness. Secara rinci Kobasa (1979 dalam Maddi, dkk, 1982) menjelaskan ketiga aspek tersebut sebagai berikut:

a. Commitment (Komitmen), lawannya alienated (pengasingan diri)

Commitment adalah sikap dan tidakan yang bersunguhsunguh dalam apapun yang dikerjakanya. Orang - orang yang memiliki komitmen lebih tulus dan kosisten dalam pekerjaan dan apapun yang sedang dihadapinya. Di samping

58 | Journal An-nafs: Vol. 4 No. 1 Juni 2019 
itu, individu yang komitmennya kuat dan tidak akan mudah menyerah pada tekanan .

b. Control (kontrol diri), lawannya poweriessness (ketidakberdayaan)

Control diri mempertinggi perlawanan terhadap stress dengan meningkatkan kemungkinan bahwa setiap kejadian akan dialami sebagai perkembangan yang dialami dari tindakan seseorang. Dalam menyelesaikan masalah kemampuan akan kontrol mampu mengubah setiap kejadian menjadi sesuatu yang konsisten dengan tujuan hidup yang telah direncanakan .

c. Challenge (tantangan), lawannya theatened (ancaman) Challenge adalah situasi atau keaadaan baru yang penuh rintangan, dan individu cenderung memandang suatu yang wajar. dan dapat mengatasi rintangan ataupun perubahan itu sebagai sesuatu yang sangat bermanfaat bagi pengetahuan individu dalam perkembangan hidup selajutnya, karena stress dianggap bukan sebagai ancaman tetapi sebagai suatu tantangan.

Maddi, dkk (dalam Coon, 2005) menjelaskan bahwa kelompok individu yang memiliki kepribadian hardiness tampaknya memiliki cara pandang yang terdiri dari:

a. Adanya perasaan akan Commitment pribadi baik untuk diri sendiri, pekerjaan,keluarga maupun nilai - nilai lain yang sesuai. Orang -orang yang mempunyai komitmen yang kuat mampu mengubah sesuatu yang mereka lakukan menjadi sesuatu pekerjaan yang penting dan menarik. Mereka merasa benar - benar terlibat dalam pekerjaannya daripada merasa terasing (alienated).

b. Adanya kemampuan akan kontrol terhadap kehidupan dan pekerjaannya.

Orang -orang yang memiliki control yang kuat akan mempengaruhi dan menjadi penyebab dari kejadian kejadian disekitarnya. Hal ini mencegahnya dari kondisi pasif yang seringkali menjadi korban dari sekelilingnya. 
Uswatun Hasanah | Hubungan Hardiness dengan Emotion

c. Adanya kecenderungan untuk melihat hidup sebagai sebuah rentetan tantangan (challenge), daripada menganggap hidup sebagai rentetan ancaman atau masalah. Sebaliknya, individu yang merasa terancam (threatened) menganggap sesuatu itu harus stabil. Adanya suatu perubahan akan dianggap merusak dan menimbulkan rasa tidak aman.

\section{Emotion-focused Coping}

Lazarus (dalamWidahastuti dan Tjahjono, 1999) mengatakan emotion-focused coping yaitu upaya mencari dan memperoleh rasa nyaman dan memperkecil tekanan yang dirasakan, emotion-focused coping ini dapat berbentuki identifikasi, represi, denial, proyeksi, reaksiformasi, displacement dan rasionalilsasi.

Menurut Sarfino (1998), Emotion-focused Coping adalah merupakan pengaturan respon emotional dari situasi yang penuh stres. Individu dapat mengatur respon emosinya dengan beberapa cara, antara lain yang biasa digunakan individu dalam pengatura nemosinya adalah dengan berfikir dan memberikan penilaian mengenai situasi yang penuht ekanan. Emotion-focused coping digunakan individu untuk mengatur respon emotional terhadap stress. Pengaturan ini melalui perilaku individu untuk meniadikan fakta-fakta yang tidak menyenangkan melalui strategi kognitif. Emotion-focused coping cenderung dilakukan apabila tidak mampu atau merasa tidak mampu mengubah kondisi yang stressfull yang dilakukan ndividu dengancara mengatur emosinya sedemikian rupa.

\section{Faktor-faktor yang mempengaruhi Emotion-focused Coping (EFC)}

Adapun faktor-faktor yang mempengaruhi emotionfocused coping yaitu :

a. Jenis kelamin

Angka suasana hati depresi menjadi lebih tinggi untuk remaja perempuan (Nolen-Hoeksema, 2007) Menurut pendapat 
Billings dan Moos (1984) wanita lebih cenderung berorientasi pada emosi sedangkan laki-laki lebih berorientasi pada tugas dalam mengatasi masalah, sehingga wanita diprediksi akan lebih sering menggunakan emotion-focused coping dari pada problemfocused coping.Berdasarkan hasil penelitian Widiyanti (2001) mengungkap bahwa perempuan dalam menggunakan strategi coping lebih sering menggunakan emotion-focused coping, sedangkan laki-laki sering menggunakan problem-focused coping. b. Pengalaman

Semakin banyak pengalaman seseorang maka semakin banyak pula alternatif yang digunakan dalam strategi coping. Faktor ini tidak diragukan lagi akan sangat mempengaruhi teknik coping yang digunakan, semakin banyak pengalaman hidup seseorang akan semakin banyak alternatif yang digunakan dalam coping.

c. Psikologis

Faktor ini sangat mempengaruhi individu dalam menggunakan strategi coping, kondisi kejiwaan individu sangat membantu seseorang dalam menemukan teknik yang sebaiknya digunakan. Keadaan psikologis seseorang mempunyai pengaruh langsung maupun tidak langsung perilaku seseorang.Keadaan psikologis seseorang mencakup kepribadian, kematangan intelektual dan kematangan emosional yang menentukan penyesuaian dirinya yang khas terhadap lingkungan (Calvin dalam Asra, 2002).

Adanya kestabilan emosi membangkitkan peristiwa peristiwa yang tidak diinginkan terjadi seperti mementingkan diri sendiri, hilangnya etika moral, ketidak mampuan berempati pada orang lain, sehingga tidak mampu menyesuaikan dengan diri dan lingkungan. Sebaliknya orangyang emosinya matang mampu menyesuaikan masalah cenderung kurang efektif. Bukti - bukti menunjukkan bahwa emosi berupa cemas maupun marah berpengaruh buruk pada kesehatan kardiovaskular seseorang (Nevid, dkk, 2005). 
Uswatun Hasanah | Hubungan Hardiness dengan Emotion

\section{Anak Yang Berhadapan dengan Hukum (ABH)}

Remaja merupakan masa transisi dari masa kanak - kanak menuju dewasa yang akan menimbulkan berbagai macam perubahan baik pada aspek fisik, seksual, emosional,reliji, moral,sosial maupun intelektul.

Dalam Undang-undang Republik Indonesia Nomor : 11 tahun 2012 Ps.1 h.4 menyebutkan bahwa Anak yang Berhadapan dengan Hukum $(\mathrm{ABH})$ adalah anak yang berkonflik dengan hukum, anak yang menjadi korban tindak pidana, dan anak yang menjadi saksi tindak pidana. Anak yang berkonflik dengan hukum selanjutnya disebut anak yang telah berumur 12 (dua belas) tahun tetapi belum berumur 18 (delapan belas ) tahun yang diduga melakukan tidak pidana.

\section{Metode Penelitian}

Untuk mendapatkan data yang diperlukan dalam penelitian ini, menggunakan dua macam angketyaitu: (1) Hardiness, (2) Emotion-fokused coping (EFC) yang disusun oleh peneliti sendiri.

\section{Paparan Data}

Pengambilan data dalam penelitian ini dilakukan pada tanggal 14 sampai dengan 16 Januari 2019. Penelitian ini dilakukan di wilayah Jombang. sebanyak 60 Anak remaja yang sedang berhadapan dengan hukum secara kesuluruhan yang diguanakan sebagai sampel penelitian.

Prosedur pelaksanaan penelitian adalah sebagai berikut :

a. Penyebaran angket diberikan kepada siswa 60 masingmasing terbagi dalam 2 ruang kelas dalam waktu secara bersamaan.

b. Dua angket diberikan dalam dalam waktu dua hari, satu hari untuk angket pertama, satu hari kemudian angket ke dua.

c. Waktu yang digunakan untuk menjawab pertanyaan pada skala penelitian tiap angket yang 60 menit. 
d. Setelah semua sampel menjawab dengan baik kemudian dikumpulkan kembali oleh peneliti dan kemudian dilakukan skoring dan tabulasi data.

Hasil korelasi antara variable hardiness dengan Emotionfokused coping (EFC), yang dilakukan dengan analisis korelasi product moment dari Karl Pearson dengan jumlah subyek $\mathrm{N}=60$ diperolehkoefesienrxy $=0,437 ; p=0,038(p<0,001)$, berarti hasil analisis tersebut menunjukan ada hubungan yang sangat signifikan antara hardiness dengan Emotion-fokused coping .

\section{Pembahasan}

Hasil analisis dengan menggunakan korelasi product moment dari Pearson dalam penelitian ini menunjukan bahwa ada hubungan yang sangat signifikan antara kepribadian hardines dengan Emotion-fokused copingpada anak remaja yang sedang berhadapan dengan hukum $(\mathrm{ABH})$. Dengan peluang kesalahan kurang dari $1 \%$. Hal ini ditunjukan oleh nilai probabilitas (p) yang diperoleh sebesar $0,005(0<0,01)$ hal ini menunjukan bahwa hardines memiliki hubungan yang sangat signifikan dengan Emotion -fokused coping, artinya seseorang anak remaja berhadapan dengan hukum $(\mathrm{ABH})$ yang memiliki kepribadian hardines yang merupakan kepribadian ketabahan(hardinees) maka individu tersebut dapat melakukan pengaturan emosi dalam menghadapi stressor secara baik dan tepat disebut Emotionfokused coping (EFC) positif, Remaja dalam proses untuk tumbuh akan berkembang dalam mengembangkan potensinya diharapkan memiliki coping yang positif dan lebih konstruktif dalam menghadapi stressor dan tekanan yang ada. Kemampuan mengahadapi masalah sangat dipengaruhi oleh ketahanan individu dalam memberikan perlawan dalam mengahadapi persoalan yang sedang dihadapinya khususnya dalam hal ini anak yang sedang berhadapan dengan hukum (ABH), Berdasarkan penelitian Strutton dan Lumkin (1994) menunjukan bahwa kepribadian hardiness dapat memberikan andil yang baik bagi individu dalam memilih strategi coping. Kepribadian Hardiness 
Uswatun Hasanah | Hubungan Hardiness dengan Emotion

merupakan keseluruhan karateristik kepribadian yang mempunyai fungsi sebagai sumber perlawanan pada saat individu menghadapi stress yang dicirikan dengan adanya comitmen, control dan challenge (Kobasa, dkk,1982).

Sejalan dengan pendapat Lazarus dan Folkman (1986) menyebutkan bahwa jika individu merasa tidak mampu mengatasi masalah,ia cenderung menggunakan Emotion-fokused coping (EFC) ditunjukan dengan adanyausaha yang dilakukan lebih pada pengaturan emosi dalam menghadapi stressor saat menghadapi kasus hokum dalam aktifitas anak remaja baik di rumah maupun di lingkungannya, strategi emotion focusedcoping strategi yang bersifat emosional yang mengarah pada cara pandang terhadap suatu situasi yang penuh ketegangan (stess). Penanggulangan atau penyelesaian dengan menggunakan mekanisme pembelaan psikologis, yaitu strategi bawah sadar yang melindungi ego dan menghindarkan dari kegelisahan dengan mendistorsikan keadaan. Bila individu khususnya dalam hal ini anak remaja yang sedang berhadapan dengan hukum $(\mathrm{ABH})$ Kondisi yang dialami anak yang sedang berhadapan dengan hukum dapat menimbulkan ketegangan yang mengakibatkan mereka strees dan ketika mereka merasa tidak mampu mengatasi masalah, maka ia cenderung menggunakan emotion-focused coping, yaitu mengatur respon emosi terhadap stress karena proses hukum dan kasus yang sedang dihadapi. Konseptualisasinya tentang hardiness sebagai tipe kepribadian yang penting sekali pada perlawanan terhadap stress, Hardiness dianggap menjaga seseorang tetap sehat dan kuat tabah walaupun mengalami kejadian-kejadian hidup yang penuh stress khususnya anak remaja yang sedang berhadapan dengan hukum $(\mathrm{ABH})$, mereka anak remaja yang sedang berhadapan dengan hukum (ABH) yang memiliki kepribadian hardiness sanggup memberikan nilai positif pada setiap kejadian dialaminya.Bila individu merasa tidak mampu mengatasi masalah secara langsung, maka individu cenderung menggunakan emotion-focused coping, yaitu mengatur respon emosi terhadap stress dengan menilai masalah tersebut di 
luar kendalinya atau menyangkal adanya stressor, manarik diri dari situasi. Anak remaja yang sedang berhadapan dengan hukum dalam proses untuk tumbuh dan berkembang harus mengembang potensinya dan harus memiliki tingkat ketahan yang kuat (Hardines) dalam mengahadapi masalah yang sedang dihadapinya diharapkan memiliki coping yang positif dan lebih kontruktif dalam menghadapi stressor dan tekanan yang ada, yaitu melalui penyelesaian masalah yang berfokus pada pokok permasalahan (problem focused coping) (Sarafino, 1998).

Emotion-focused coping (EFC) ditunjukkan dengan adanya usaha yang dilakukan lebih pada pengaturan emosi dalam menghadapi stressor dalam aktivitas remaja di lingkungannya. .Sebagai contoh: ketikaanak ABH memperolehmasalah degan hukum dan menjalani beberapa proses hukum sampai dipidanakan sehingga menimbulkan tekanan psikologis yang berupa hukuman dan stigna buruk dari masyarakat sekitar , maka upaya yang dilakukan adalah dengan memberikan penilaian positif terhadap masalah tersebut sebagai cobaan untuk diambil hikmahna dan mengalihkanya atau melakukan kegiatan lebih mendekatkan diri dengan Allah SWT.Bila individu merasa tidak mampu mengatasi masalah secara langsung, maka individu cenderung menggunakan emotion focused coping yaitu mengatur respon emosi terhadap sters dengan menilai masalah tersebut di luar kendalinya atau menyangkal adanya stressor, menarik diri dari situasi.

\section{Kesimpulan}

Berdasarkan hasil analisis data yang telah diuraikan, maka dapat disimpulkan bahwa terdapat hubungan yang sangat signifikan antara hardiness dengan Emotion-fokused coping.

\section{Saran-saran}

Berdasarkan hasil penelitian yang telah penulis lakukan, serta kesimpulan yang ada, maka beberapa saran dapat diajukan sebagai berikut : 
Uswatun Hasanah | Hubungan Hardiness dengan Emotion

a. Bagi remaja, hendaknya dapat menyikapi segala persoalan dengan menggunakan strategi stress yang baik, lebih mempertahankan hardiness agar dalam mengahadapi masalah dapat menekan kondisi emotion-focused coping.

b. Bagi Guru dan orang tua hendaknya untuk terus memotivasi dan membimbing pada cara penyelesaian masalah yang efektif dan lebih kontruktif dalam upaya meraih prestasi dan menghadapi tantangan yang ada.

c. Bagi peneliti selanjutnya dengan adanya penelitian ini penulis mengharapkan adanya pengembangan yang dilakukan para peneliti yang akan dating dalam pembahasan emotion-focused coping, seperti jenis kelamin, pengalaman atau cara berfikir individu, kondisi psikologis individu, usia, suasana keluarga dan tingkat pendidikan, sehingga dapat diketahui besar sumbangan efektif variabel-variabel tersebut terhadap emotion-fokused coping. 
Uswatun Hasanah | Hubungan Hardiness dengan Emotion

\section{Daftar Pustaka}

Azwar, S. 2000. Reliabilitas dan Validitas. Edisikelima. Yogjakarta: PustakaPelajar Offset.

Amstromg, Soe. 1995. Pengaruh Rokok Terhadap Kesehatan. Jakarta : Penerbit Arcan.

Beyth-Marom, R., Austin, L., Fischhoff, B., Palmgren, C., \& JacobsQuadrel, M. (1993). Perceived consequences of risky behaviors: Adults and adolescents. Journal of Developmental Psychology, 29(3), 549-563

Bandura, A. 1986. Social Faundation of Thaught and Action A Social CognitifTheory.NewJersey: Prentice-Hall, Inc.

Ekowarni, E. 1993. Kenakalan Remaja: Suatu Tinjauan Psikologi. Bulletin Psikologi. 2: 24-27.

Elfida, D. 1995. HubunganKemampuanmengontroldiri dan KecenderunganberprilakuDelikuen pada Remaja. Skripsi (tidakditerbitkan), Jogjakarta: FakultasPsikologi, Universitas Gadjah Mada.

Fishbein, M., \&Ajzen, I. 1975. Belief, attitude, intention and behavior: An introduction to theory and research. Reading, MA: Addison-Wesley.

Grinder, R.E. 1978. Adolescent Development.Second Edition. Illnois : A. Division of Scott,Foresman and Company.

Galuh,2016,Vol 2 No. 1 Hubungan antara dukungan soail dan hardiness dengan kesejateraan psikologis pada Wanita Bekerja ,Jurnal, Surakarta : Fakultas Psikologi ,Universitas Muhamdiyah

Hurlock, E.B. 1994. Adolescent Development (4th ed). Tokyo: McGraw-Hill Kogakusha Ltd.

-----------. 1978. Child Development. New York: Mc. Millan Publishing co.Inc.

Hurlock, E,B. 1999. Psikologi Perkembangan, Suatu Pendekatan sepanjang Rentang Kehidupan. (terjemahan). Jakarta: Erlangga 
Uswatun Hasanah | Hubungan Hardiness dengan Emotion

Nurjahjanti-Ratnaningsih, 2011 . Vol : 10 No. 2 , Hubungan Kepribadian Hardiness dengan Optimime pada Calon Tenaga Kerja Indonsia di BLKN Disnakertrans Jawa Tengah : Universitas Diponegoro

Hadi,Sutrino .1991. Metodelogi Research Jilid I. Yogjakarta : Penerbit Andi Offset.

Hadi. Sutrino. 2000. Manual SPS Paket MIDI. Yogjakarta : Uiversitas Gajah MadaYogjakarta.

Kobasa, S.C. (1979). Stressful Life Event Personality and Health: An Inquiry Into Hardiness. Journal of Personality and Social Psychology, 37, 1-11.

Kumpulan Peraturan Anak Berkonflik dengan Hukum (2001) Penerbit : Lembaga Advokasi Pemberdayaan Pekerja dan Anak dan Plan International, Jakarta

Mounk, F.J., Knoers, A.M.P., Haditono,S.R. 1992.Psikologi Perkembangan. Pengantar dalam Berbagai Bagiannya. Jogjakarta:GadjahMada University Press.

Olivia 2014,Vol : 2 No. 1, Kepribadian Hariness dengan Prestasi Kerja.Malang : Fakultas Psikologi Universitas Muhamdiyah

Papalia, D E., Olds, S. W., \& Feldman, Ruth D. (2001). Human development (8th ed.). Boston: McGraw-Hill

Pedoman Kerja antar Kementrian/lembaga dalam Perlindungan Rehabilitasi Sosial Anak Berhadapan dengan Hukum (2012) : Kementrian Komunikasi dan Informatika RI

Rice, F.P. (1990). The adolescent development, relationship \& culture (6th ed.). Boston: Ally \& Bacon

Suharto dkk, (2015) . Vol : V No.1, Interaksi sosial anak berhadapan dengan hukum di panti asuhan mardipura bambu apus Jakarta, : Share Jurnal Sosial Work : ISSN:2339-0042

Santrock, J.W. (2007). Adolescence (8th ed.). North America: McGraw-Hill. ISBN : 978-0-07-313372-0 
Uswatun Hasanah | Hubungan Hardiness dengan Emotion

Sarwono, S.W. 2002. PsikologiRemaja. EdisiEnam. Jakarta: Raja GrafindoPersada.

Sarafino, E.P 1998. Health Psycology, Biopsycholososial Interactions. Third Edition. New York : jhon Wiley \& Sons, Inc.

Suryabrata, S. 2000. PengembanganAlatUkurPsikologi. Yogyakarta: Penerbit Andi.

Undang-undang Republik Indonesia nomor 11 tahun 2012 tentang sistem peradilan Pidana Anak Diperbanyak oleh : Direktorat Jendral Rehabilitasi Sosial Kementrian Sosial Replubik Indonesia.

Walgito, B. 1994. Pengantar Psikologi Umum, EdisiRevisi, Cetakan keempat, Jogjakarta: Andi Offset. 